\title{
PENGARUH KOMPRES HANGAT TERHADAP PENURUNAN NYERI PADA PASIEN GOUT ARTHRITIS
}

\author{
Aldhila Putri Widyastuti ${ }^{1}$ \\ Politeknik Kesehatan Karya Husada Prodi DIII Keperawatan \\ Email : abdulaziz0165@gmail.com \\ Abdul Aziz ${ }^{2}$ \\ Politeknik Kesehatan Karya Husada Prodi DIII Keperawatan \\ Agustina Retno Hapsari ${ }^{3}$ \\ Politeknik Kesehatan Karya Husada Prodi DIII Keperawatan \\ Email : abdulaziz0165@gmail.com \\ Moebari $^{4}$ \\ Politeknik Kesehatan Karya Husada Prodi DIII Keperawatan \\ Email : abdulaziz0165@gmail.com
}

\begin{abstract}
ABSTRAK
Latar Belakang : Gout arthritis merupakan kelompok penyakit heterogen sebagai akibat deposisi kristal monosodium urat pada jaringan. World Health Organization (WHO) tahun 2017 menyatakan bahwa prevalensi gout arthritis di dunia sebanyak 34,2\%. Berdasarkan (Riskesdas) tahun 2013 di Indonesia pravelansi penyakit gout berdasarkan diagnosa tenaga kesehatan diIndonesia 11,9\%, dan berdasarkan diagnosa atau gekala 24,7\%, prevalensi usia $\geq 75$ tahun sebanyak 54,8\%. Gout arthritis yang sedang meradang dapat menyebabkan nyeri oleh karena itu diberikan terapi nonfarmakologi untuk mengurangi rasa nyeri dengan pemberian kompres hangat, kompres hangat berefek secara fisiologis dengan cara memperbaiki peredaran darah melalui proses vasodilatasi pembuluh darah, mengurangi inflamasi, menurunkan kekakuan dan nyeri. Tujuan : Literatur review ini bertujuan untuk mengetahui adanya pengaruh kompres hangat terhadap penurunan nyeri pada pasien gout arthritis. Metode : Metode penelitian ini menggunakan metode studi kepustakaan atau literature review. Sumber Pencarian jurnal dalam penelitian ini menggunakan Google Schoolar dan Freefullpdf dengan kata kunci : Gout Arthritis, Kompres Hangat, Nyeri. Hasil : Berdasarkan dari kelima jurnal tentang pengaruh kompres hangat terhadap penurunan nyeri pada pasien gout arthritis di dapatkan hasil uji statistik dari kelima jurnal menggunakan uji wilcoxon dan uji T-test, kompres hangat efektif untuk menurunkan nyeri pada pasien gout arthritis dengan hasil $p$ value $<0$,05.Kesimpulan : Terdapat pengaruh yang signifikan antara kompres hangat terhadap penurunan nyeri pada pasien gout arthritis.
\end{abstract}

Kata Kunci : Gout Arthritis, Kompres Hangat, Nyeri

\section{ABSTRACT}

Background: Gout arthritis is a heterogeneous group of diseases as a result of monosodium urate crystal deposition in tissues. The World Health Organization (WHO) in 2017 stated that the prevalence of gouty arthritis in the world was 34.2\%. Based on (Riskesdas) in 2013 in Indonesia the prevalence of gout based on the diagnosis of health workers in Indonesia was $11.9 \%$, and based on diagnosis or symptoms of $24.7 \%$, the prevalence of age 75 years was $54.8 \%$. Gout arthritis that is inflamed can cause pain, therefore non-pharmacological therapy is given to reduce pain by giving warm compresses, warm compresses have a physiological effect by improving blood circulation through the process of vasodilatation of blood vessels, reducing inflammation, reducing stiffness and pain. Objective: This literature review aims to determine the effect of warm compresses on reducing pain in gouty arthritis patients. Methods: This research method uses the method of literature review or literature review. Source Search journals in this study using Google Schoolar and Freefullpdf with the keywords: Gout Arthritis, Warm Compresses, Pain. Results: Based on the five journals about the effect of warm compresses on reducing pain in gout arthritis patients, statistical test results from the five journals using the Wilcoxon test and T-test, warm compresses are effective for reducing pain in gout arthritis patients with $p$ value $<0,05$. Conclusion: There is a significant effect of warm compresses on reducing pain in patients with gout arthritis. 


\section{PENDAHULUAN}

Gout arthritis merupakan kelompok penyakit heterogen sebagai akibat deposisi kristal monosodium urat pada jaringan (Dianati, 2015) Gout arthritis paling banyak terdapat pada sendi jempol kaki, sendi pergelangan, sendi kaki, sendi lutut dan sendi siku yang dapat menyebabkan nyeri yang sedang meradang karena adanya penumpukan zat purin yang dapat membentuk kristalkristal yang mengakibatkan nyeri. Nyeri yang dialami tidak segera ditangani akan mengakibatkan gangguan terhadap aktivitas fisik sehari-hari seperti menurunnya aktivitas fisik (Nahariani,dkk,2015). Ada beberapa faktor yang mempengaruhi peningkatan kadar asam urat menjadi tinggi salah satunya adalah perilaku hidup tidak sehat seperti mengkonsumsi makanan yang mengandung purin tinggi, mengkonsumsi alkohol dan obesitas (Zahara, 2013).

Berdasarkan data World Health Organization (WHO, 2017), prevalensi gout arthritis di dunia sebanyak 34,2\%. Di Indonesia prevalensi penyakit gout berdasarkan diagnosa tenaga kesehatan diIndonesia $11,9 \%$, dan berdasarkan diagnosis atau gejala $24,7 \%$, prevalensi usia $\geq 75$ tahun sebanyak 54,8\%. Angka ini menunjukkan bahwa penyakit nyeri akibat asam urat sudah sangat menganggu aktivitas masyarakat Indonesia (Riskesdas, 2013).

Penanganan gout arthritis dapat dilakukan dengan dua cara pengobatan yaitu secara farmakologis dan secara non farmakologis. Pengobatan secara farmakologis dilakukan dengan cara pemberian kelompok obat anti-inflamasi nonsteroid (OAINS) untuk mengatasi nyeri dan peradangan sendi, kemudian kelompok obat inhibitor xanthine oxidase (IXO) untuk meningkatkan pengeluaran asam urat, dan untuk menghambat produksi asam urat digunakan kelompok obat urikosurik Lingga (2012), akan tetapi penggunaan obat antiinflamasi nonsteroid (OAINS) dalam jangka waktu yang lama dan berturut-turut akan ada efek samping yang tidak baik pada gastroinetstinal dan ginjal. Efek samping obat anti-inflamasi nonsteroid (OAINS) pada gastrointestinal bisa menyebabkan perdarahan saluran cerna bagian atas, ulkus atau perforasi dan obstruksi serta dispepsia, sedangkan efek samping untuk ginjal dapat mempengaruhi kesimbangan elektrolit dan kerusakan fungsi ginjal berupa nefritis interstisialis atau nekrosis papilaris, dan gagal ginjal akut (Perhimpunan Reumatologi Indonesia, 2014).

Untuk pengobatan nonfarmaologis dilakukan dengan cara edukasi pasien mengenai gout arthritis, dengan terapi diet makanan yatu dengan menghindari makanan tinggi purin, olahraga, dan kompres hangat (Hikmatyar, 2017). Pemberian kompres hangat adalah tindakan yang dilakukan untuk melancarkan sirkulasi darah juga untuk menghilangkan rasa sakit. Pemberian kompres dilakukan pada radang persendian (Riyadi, 2012), dan dengan kompres hangat bisa meminimalkan efek samping dari penggunan obat.

Pada penderita gout arthritis yang mengalami nyeri pemberian kompres hangat berefek secara fisiologis dengan cara memperbaiki peredaran darah melalui proses vasodilatasi pembuluh darah, menurunkan nyeri penderita gout atrhritis yang menuju ke jaringan tubuh, mengurangi inflamasi, menurunkan kekauan dan nyeri (Wurangin, dkk. 2014).

Berdasarkan uraian latar belakang masalah diatas maka penulis tertarik untuk melakukan studi kasus dengan literatur review mengenai pengaruh kompres hangat terhadap penurunan nyeri pada pasien gout arthitis.

\section{TUJUAN}

Tujuan penelitian, untuk pengaruh kompres hangat terhadap penurunan nyeri pada pasien gout atrhitis 
Aldhila Putri Widyastuti : Pengaruh Kompres Hangat Terhadap Penurunan Nyeri Pa\&6 Pasien Gout Arthritis

\section{KAJIAN LITERATUR KOMPRES HANGAT}

\section{Pengertian}

Kompres hangat merupakan terapi non farmakologis untuk menghilangkan atau menurunkan rasa nyeri dengan memberikan rasa hangat, memenuhi kebutuhan rasa nyaman, mengurangi atau membebaskan rasa nyeri, dan mengurangi terjadinya spasme otot dengan menggunakan air hangat. (Hidayat, 2015, cit. Hoesny, dkk, 2018)

Kompres hangat merupakan metode pemeliharaan suhu tubuh dengan menggunakan cairan atau alat yang dapat menimbulkan hangat atau dingin pada bagian tubuh yang memerlukan dengan tujuan untuk memperlancar sirkulasi darah, dan mengurangi rasa sakit atau nyeri. Dalam keperawatan menurut Andarmoyo (2013)

Kompres hangat dapat menyebabkan dilatasi pembuluh sehingga akan memperbaiki peredaran pada jaringan yang dikompres. Dengan cara ini penyaluran zat asam dan bahan makanan ke sel-sel diperbesar dan pembuangan dari zat-zat yang dibuang akan diperbaiki. Aktivitas sel meningkat akan mengurangi rasa nyeri dan akan menunjang proses penyembuhan, (Steven, 2014, cit. Zahroh, 2018)

\section{Manfaat Kompres Hangat}

(Rezky, 2013, cit. Zahroh, 2018 ) manfaat kompres hangat dapat memfokuskan perhatian pada sesuatu selain nyeri, tindakan pengalihan seseorang tidak terfokus pada nyeri lagi, dan dapat menjadi relaksasi,meperlancar atau melebarkan sirkulasi darah, meredakan nyeri dengan mengurangi spasme otot.

Meningkatkan aliran darah ke bagian tubuh yang mengalami cedera, meningkatkan relaksasi otot dan mengurangi nyeri akibat spasme atau kekakuan, meningkatkan aliran darah dan meningkatkan pergerakan zat sisa dan nutrisi (Wurangin, dkk, 2014)

\section{Indikasi Kompres Hangat}

Menurut (Fanada, 2012, cit. Yuda,dkk, 2017) kompres hangat dapat diberikan pada :

a. Klien dengan perut kembung.

b. Klien dengan demam. c. Klien yang mengalami peradangan sendi.

d. Klien dengan kekejangan pada otot.

e. Klien yang mengalami inflamasi.

4. Mekanisme Kompres Hangat Terhadap Penurunan Nyeri

Hangat dapat mengurangi spasme otot yang memblok transmisi lanjut rangsang nyeri yang menyebabkan terjadinya vasodilatasi dan peningkatan aliran darah didaerah yang dilakukan (Rohimah S\& E, 2015). Pemberian kompres hangat adalah intervensi keperawatan yang sudah lama diaplikasikan oleh perawat, kompres hangat dianjurkan untuk menurunkan nyeri karena dapat meredakan nyeri, meningkatkan relaksasi otot, melancarkan sirkulasi darah, meningkatkat relaksasi psikologis, dan memberi rasa nyaman ( Koizier \& Erb, 2009, cit. Ardani, 2019)

\section{GOUT ARTHRITIS}

\section{Pengertian}

Gout artrhitis merupakan penyakit yang ditandai dengan inflamasi sendi yang nyeri, dan sering terjadi pada sendi metatarsophalangeal, yang disebabkan akibat persipitasi kristal monosodium urat di sendi, gout di dominasi oleh laki-laki. Pada perempuan gout jarang terjadi sebelum menopause (Sembiring, 2018).

Gout arthritis adalah jenis penyakit pada sendi akibat terlalu banyak asam urat di tubuh. Rasa sakit biasanya terjadi di jempol kaki, juga pembengkakan dan nyeri di mata kaki, lutut, pergelangan tangan, atau siku. Rasa sakit terjadi selama beberapa hari pada awalnya dan kemudian bisa berkembang lebih lama. Bila dibiarkan tak terawat, gout bisa menyebabkan kerusakan permanen pada persendian dan ginjal. Gout lebih umum menyerang laki-laki berusia 40-50 tahun (Kurnia, 2019).

Seseorang akan dikatakan asam urat jika kadar asam urat dalam darahnya di atas 7 $\mathrm{mg} / \mathrm{dl}$ untuk laki-laki, dan untuk wanita $6 \mathrm{mg} / \mathrm{dl}$. Penyakit gout terjadi karena penimbunan kristal asam urat yang meningkat pada persendian (Wijayakusuma, 2008, cit. Sukarmin 2015) 


\section{Etiologi Gout Arthritis}

Menurut Hermayudi \& Ariani (2017) . Faktorfaktor yang berpengaruh sebagai penyebab gout adalah :

a. Faktor keturunan dengan adanya riwayat gout dalam silsilah keluarga.

b. Meningkatnya kadar asam urat karena makanan kaya senayawa purine lainnya. Purine adalah senyawa yang akan dirombak menjadi asam urat dalam tubuh.

c. Konsumsi alkohol berlebih, karena alkohol merupakan salah satu sumber purine yang juga dapat menghambat pembuangan urine melalui ginjal.

d. Hambatan dari pembuangan asam urat karena penyakit tertentu, terutama gangguan ginjal. Pasien disarankan meminum cairan dalam jumlah banyak. Minum air sebanyak 2 liter atau lebih tiap harinya membantu pembuangan urat, dan meminimalkan pengendapan urat dalam saluran kemih.

e. Penggunaan obat-obat tertentu yang meningkatkan kadar asam urat, terutama diuretik (furosemid dan hidroklorotiazida).

f. Penyakit tertentu dalam darah (anemia kronis) yang menyebabkan terjadinya gangguan metabolisme, misal berupa gejala polisitomia dan leukemia.

g. Faktor lain seperti stress, diet ketat, cedera sendi, darah tinggi dan olahraga berlebihan.

\section{Manifestasi Klinis Gout Arthritis}

Menurut Hermayudi \& Ariani (2017) tanda dan gejala gout arthritis secara umum adalah sebagai berikut :

a. Nyeri hebat yang tiba-tiba menyerang sendi pada saat tengah malam, biasanya pada ibu jari kaki (sendi metatarsofalangeal pertama) atau jari kaki (sendi tarsal).

b. Kulit bewarna kemerahan, terasa panas, bengkak, dan sangat nyeri.

c. Pembengkakan sendi umumnya terjadi secara asimetris (satu sisi tubuh). d. Demam, dengan suhu tubuh $38,3^{\circ} \mathrm{C}$ atau lebih, tidak menurun lebih dari tiga hari walau dilakukan perawatan.

e. Bengkak pada kaki.

\section{Penatalaksanaan Gout Arthritis}

Penatalaksanaan utama pada penderita arthritis gout meliputi edukasi pasien tentang diet yaitu menghindari makanan yang mengandung tinggi purin Penderita gout arthritis juga harus mengubah gaya hidupnya dengan baik mengkonsumsi makanan yang sehat, tidak merokok, latihan fisik secara rutin 3-5 kali seminggu selama 30-60 menit. Olahraga ini bertujuan untuk menjaga berat badan ideal dan menghindari terjadinya gangguan metabolisme (Perhimpunan Rheumatologi Indonesia, 2018). Untuk mengurangi nyeri, kompres hangat dapat diberikan sebagai salah satu terapi nonfarmakologis (Kalim, dkk, 2019)

Pengobatan arthritis gout bergantung pada tahap penyakitnya. Hiperurisemia asimptomatik biasanya tidak membutuhkan pengobatan. Serangan akut gout arthritis diobati dengan obat-obatan antiinflamasi nonsteroid atau kolkisin. Obat-obat ini diberikan dalam dosis tinggi atau dosis penuh untuk mengurangi peradangan akut sendi (Carter, 2006, cit. Widyanto, 2014).

\section{NYERI AKUT}

\section{Pengertian Nyeri}

Nyeri merupakan suatu perasaan atau pengalaman yang tidak nyaman baik secara sensori maupun emosional yang dapat ditandai dengan kerusakan jaringan ataupun tidak menggambarkan nyeri sebagai perasaan yang tidak menyenangkan dan pengalaman emosional yang dihubungan dengan aktual atau potensial kerusakan jaringan tubuh (Syamsiah, 2015, cit. Hoesny)

Nyeri adalah pengalaman sensorik dan emosional yang tidak menyenangkan akibat kerusakan jaringan, baik secara aktual, maupun potensial (Wiarto, 2017, cit. Feron, 2019)

\section{Jenis-Jenis Nyeri}


Aldhila Putri Widyastuti : Pengaruh Kompres Hangat Terhadap Penurunan Nyeri Pas8 Pasien Gout Arthritis

Jenis-jenis nyeri menurut Sari (2016) Verbal Pain Intensity Scale adalah :

a. Nyeri akut atau sementara

Nyeri akut memiliki penyebab yang dapat diidentifikasi, berdurasi pendek, dan memiliki sedikit kerusakan jaringan serta respons emosional, berintensitas ringan hingga berat yang berlangsung kurang dari tiga bulan.

b. Nyeri kronis atau menetap

Nyeri kronis berlangsung lebih lama. Nyeri kronis yaitu pengalaman sensorik atau emosional yang berkaitan dengan kerusakan jaringan aktual atau fungsional, dengan onset mendadak atau lambat dan berintensitas ringan hingga berat dan konstan yang berlangsung lebih dari tiga bulan

\section{Pengukuran Skala Nyeri}

Pengukuran tingkat nyeri menurut (Pamungkas,2019 ; Yudiyanta, dkk, 2015)

a. Numerica Racting Scale (NRS)

Numerica Racting Scale (NRS) di pengukuran menggunakan skala angka 1-10 untuk menggambarkan kualitas nyeri yang dirasakan oleh pasien. NRS lebih mudah dipahami, NRS juga lebih efektif untuk mendeteksi penyebab nyeri akut ketimbang Visual Analog Scale (VAS) dan Verbal Rating Scale (VRS). Akan tetapi kekurangan dari NRS adalah keterbatasan pilihan kata untuk menggambarkan rasa nyeri, tidak memungkinkan untuk membedakan tingkat nyeri dengan lebih teliti.

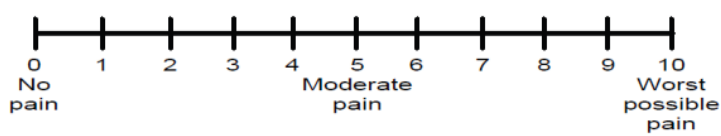

b. Verbal Rating Scale (VRS)

Verbal Rating Scale (VRS) menggunakan dua ujung yang sama seperti Visual Analog Scale (VAS). Skala verbal menggunakan katakata dan bukan gari atau angka untuk menggambarkan tingkat nyeri. Sakala yang digunakan dapat berupa tidak ada nyeri, sedang, parah.
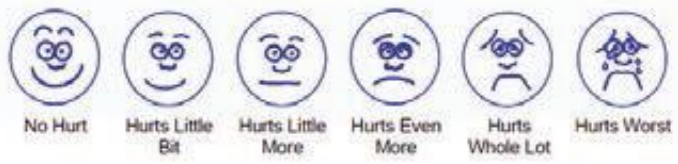

\section{Penatalaksanaan Nyeri}

Wahyudi (2016), cit. (Feron, 2019) mengemukakan bahwa pentalaksanaan nyeri adalah suatu tindakan untuk mengurangi nyeri baik menggunakan teknik farmakologis ataupun nonfarmakologis, meliputi:

a. Farmakologis 
Penatalaksanaan dengan farmakologis yang dilakukan yaitu dengan pemberian obat analgesik atau obat penghilang rasa nyeri. Obat-obat yang diberikan dapat di golongkan ke dalam obat analgesik narkotik dan analgesik non narkotik. Analgesik narkotik terdiri dari berbagai derivate opium seperti morfin dan kodein sedangkan untuk analgesik non narkotik seprti aspirin, asetaminofen, dan ibuprofen selain memiliki efek anti nyeri juga memiliki anti inflamasi dan antipiretik.

Untuk pengobatan nyeri pada sendi jenis Nonsteroidal Anti-inflammatory Drugs (NSAID) adalah aspirin dan ibuprofen (afren).

b. Nonfarmakologis

Penanganan nyeri secara nonfarmakologis dapat dilakukan dengan cara :

1) Relaksasi progresif

Relaksasi adalah kebebasan mental dan fisik dari ketegangan stress. Teknik relaksasi memberikan individu kontrol diri ketika terjadi rasa tidak nyaman atau nyeri, stres fisik, dan emosi pada nyeri.

2) Teknik distraksi

Distraksi adalah metode untuk menghilangkan nyeri dengan cara mengalihkan perhatian pasien pada hal-hal lain, sehingga pasien lupa terhadap nyeri yang dialaminya.

3) Kompres hangat

Pemberian kompres hangat merupakan cara yang baik dalam menurunkan atau meredakan nyeri. Pemberian kompres hangat bisa diberikan menggunakan handuk hangat, botol berisi air hangat, buli-buli panas.

\section{METODE}

Penelitian ini merupakan studi kepustakaan atau literatur review, yang bertujuan untuk mengumpulkan dan mengambil intisari dari penelitian sebelumnya serta menganalisis beberapa overview para ahli yang tertulis dalam artikel (Snyder, 2019). Literatur review memiliki peran sebagai landasan bagi berbagai jenis penelitian karena hasil literatur review memberikan pemahaman tentang perkembangan pengetahuan, seumber stimulus pembuatan kebijakan, memantik penciptaan ide baru dan berguna sebagai panduan untuk penelitian bidang tertentu.

Data yang digunakan dalam penelitian ini berasal dari hasil-hasil penelitian yang sudah dilakukan dan diterbitkan dalam jurnal online nasional. Dalam melakukan penelitian ini penulis melakukan pencarian jurnal penelitian yang dipublikasikan di internet menggunakan Google Schoolar, Freefullpdf. Dengan kata kunci : Gout Arthritis, Kompres Hangat, Nyeri.

Jurnal yang direview adalah original jurnal fulltext dengan subyek manusia dewasa tentang pengaruh kompres hangat terhadap penurunan nyeri pada pasien gout arthritis, dengan rentang waktu penerbitan jurnal 20102020. Jurnal penelitian yang ditemukan sesuai dengan kata kunci, selanjutnya dilakukan skrinning, dilihat dari abstrak kemudian dibaca artikel secara keseluruhan.

Jurnal penelitian yang sesuai dengan kriteria insklusi kemudian dikumpulkan dan dibuat ringkasan jurnal meliputi nama peniliti, tahun terbit, penerbit jurnal, lokasi penelitian (Kota atau Negara), tujuan, metode, sample, dan ringkasan hasil atau temuan. Ringkasan jurnal penelitian tersebut dimasukkan ke dalam tabel diurutkan sesuai alfabet dan tahun terbit jurnal. Untuk lebih memperjelas analisis abstrak dan full texs jurnal dibaca dan dicermati. Ringkasan jurnal terebut kemudia dilakukan analisis tehadap isi yang terdapat dalam tujuan penelitian dan hasil atau temuan penelitian. Metode analisis yang digunakan menggunakan isi jurnal.

\section{HASIL}

Penelusuran melalui Google Scholar dengan kata kunci : gout arthritis, kompres hangat, nyeri, penulis menemukan 597 jurnal yang sesuai dengan kata kunci tersebut. Sebanyak 124 jurnal dari 597 jurnal yang ditemukan sesuai kata kunci tersebut dilakukan skrinning. Sebanyak 109 jurnal diekslusi karena tidak tersedia artikel full text. Dari 15 jurnal full text diskrinning kembali berdasarkan kriteria inklusi yang sudah ditentukan. Dan sebanyak 10 jurnal dieksklusi, sehingga didapatkan 5 jurnal full text yang dilakukan review. 


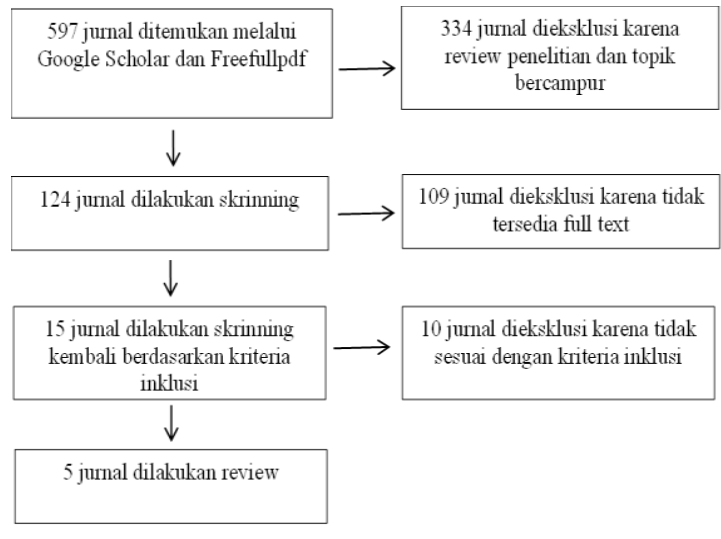

Dari lima jurnal yang direview diketahui terdapat perubahan rerata skala nyeri sebelum dan sesudah diberikan kompres hangat. Pada ke-5 penelitian menunjukkan bahwa responden yang diberikan kompres hangat efektif membantu menurunkan nyeri pada penderita gout arthritis. Pada responden yang diberikan kompres hangat penurunan rata-rata skala nyeri terbesar yaitu 3,47 dari rerata skala nyeri 6,93 menjadi 3,46 yang diteliti oleh Sandy Kurnia Jati, dkk (2015).

\begin{tabular}{|c|c|c|c|}
\hline Pene liti Jurnal & $\begin{array}{l}\text { Sebelum } \\
\text { intervensi }\end{array}$ & $\begin{array}{l}\text { Sesudah } \\
\text { intervenci }\end{array}$ & Perubahan \\
\hline $\begin{array}{l}\text { Sandy Kurnia Jati, } \\
\text { ditk(2015) }\end{array}$ & 6,93 & 3,46 & 3,47 \\
\hline $\begin{array}{l}\text { Mellynda } \\
\text { Wurangin, dik } \\
(2014)\end{array}$ & 6,23 & 3,30 & 2,93 \\
\hline $\begin{array}{l}\text { Muhammad Risal } \\
(2019)\end{array}$ & 6,24 & 3,30 & 2.94 \\
\hline Hasnd,dtk (2018) & 2,4 & 1,3 & 1,1 \\
\hline Melti Suriya (2016) & 6,75 & 5,58 & 1,17 \\
\hline Jumlah & 5,71 & 3,38 & 2,32 \\
\hline
\end{tabular}

Kelima jurnal yang dianalisis menunjukkan bahwa terdapat pengaruh kompres hangat terhadap penurunan nyeri pada penderita gout. Penelitian yangdilakuan Sandy Kurnia Jati, dkk, (2015) terhadap 32 responden yang diberikan kompres hangat menunjukkan adanya perubahan rerata skala nyeri dari sebelum diberikan kompres hangat 6,93 dan setelah diberikan kompres hangat 3,46 dengan rata-rata perubahan skala nyeri sebesar 3,47. Hasil uji wilcoxon diperoleh hasil $P=0,000<0,05$ berarti $\mathrm{H}_{0}$ ditolak dan $\mathrm{H}_{1}$ diterima, maka terdapat pengaruh kompres hangat dalam penurunan nyeri pada penderita asam urat

Penelitian Mellynda Wurangin ,dkk (2014) terhadap 30 responden yang diberikan kompres hangat rerata skala nyeri sebelum diberikan kompres hangat 6,23, setelah diberikan kompres hangat turun menjadi 3,30. Rerata perubahan skala nyeri sebelum dan sesudah treatmen sebesar 2,93. Hasil uji wilcoxon terhadap perbedaan rata-rata skala nyeri sebelum dan sesudah diberikan kompres hangat dengan $P=0,000<0,05$, dapat disimpulkan bahwa terdapat penurunan skala nyeri yang signifikan sebelum dan sesudah diberikan kompres hangat.

Sebanyak 28 responden dengan gout arthritis rata-rata skala nyeri sebelum diberikan kompres hangat 6,24, setelah diberikan kompres hangat menjadi 3,30. Rerata skala nyeri turun sebesar 2,94. Uji beda mean denagn wilcoxon diketahui nilai $P=0,000$ dan $\alpha=0,05$, jadi $P<\alpha$. Terdapat pengaruh yang signifikan pemberian kompres hangat terhadap penurunan nyeri pada penderita gut arthritis (Muhammad Risal, 2019)

Penelitian terhadap 20 responden gout arthritis diketahui rerata skala nyeri sebelum diberikan kompres hangat 2,4. Setelah diberikan kompres hangat rerata skala nyeri turun menjadi 1,3 . Perubana skala kala nyeri sebelum dan setelah treatmen sebesar 1,1. Dari hasil uji statistic wilcoxon di dapatkan $P=0,000$. Kesimpulannya terdapat pengaruh yang signifikan pemberian kompres hangat terhadap penurunan nyeri pada pasien gout arthritis (Hasrul,dkk, 2018)

Jurnal ke lima dengan 24 responden, 12 responden di lakukan kompres air hangat dan sisanya dilakukan kompres menggunakan kompres jahe. Rerata skala nyeri dari pada kelompok kompres air hangat sebelum diberikan kompres air hangat 6,75, setelah diberikan kompres hangat 5,58 dengan rerata perubahan skala nyeri sebesar 1,17 . Nilai $\mathrm{P}$ pada uji statistic sebesar 0,002 , terdapat penurunan signifikan rerata skala nyeri sebelum dan sesudah diberikan kompres hangat (Melti Suriya, 2016). 


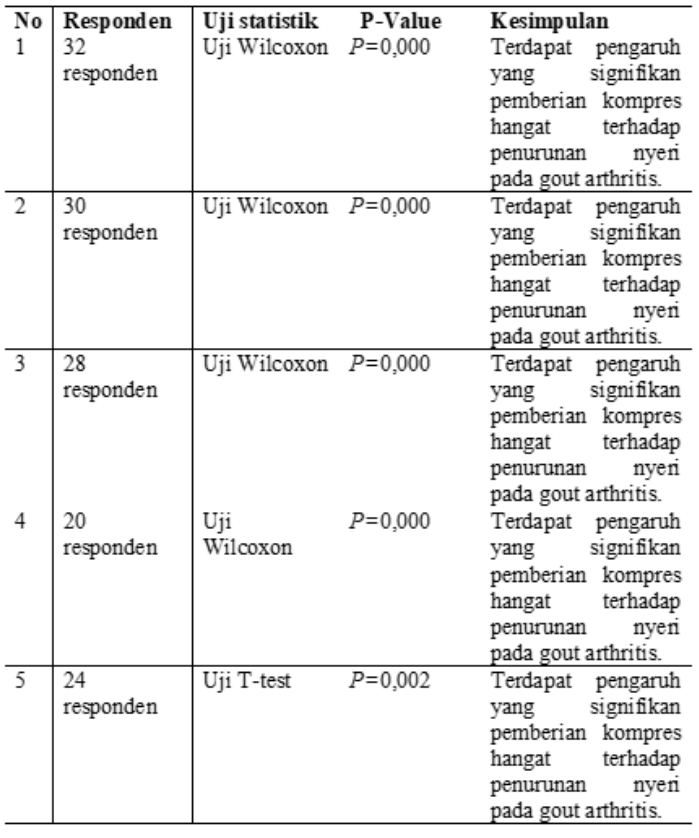

\section{PEMBAHASAN}

Analisis dari kelima jurnal diatas rentang usia penderita gout arthritis usianya > 30 tahun - 84 tahun dan terdapat laki laki sebanyak 47 responden dengan 35\%, perempuan sebanyak 63 responden dengan 47\%. Gout arthritis terjadi pada laki-laki dewasa berusia $\geq 30$ tahun dan wanita setelah menopuse atau berusia $\geq 50$ tahun (Dianati,2015).

Dari kelima jurnal yang direview semuanya secara signifikan menunjukkan bahwa kompres hangat efektif untuk menurunkan nyeri pada penderita gout arthritis, dimana rerata skala nyeri dari kelima jurnal sebelum diberikan kompres hangat 5,71 dan setelah diberikan kompres hangat 3,38 terdapat perubahan rerata skala nyeri dari kelima jurnal sebesar 2,32.

Dengan hasil penurunan rerata skala nyeri diatas maka terbukti bahwa kompres hangat dapat menurunkan nyeri secara efektif. Hal tersebut sejalan dengan teori yang dinyatakan oleh (Amilia Rezky, 2013) bahwa nyeri asam urat dapat diatasi secara non farmakologis dengan kompres hangat, dimana kompres hangat dapat melancarkan aliran darah serta menurunkan ketegangan otot sehingga nyeri asam urat dapat berkurang.
Penelitian oleh Siregar, dkk (2018) terhadap 17 responden yang menderita gout arthritis, diketahui sebelum diberikan kompres hangat rerata skala nyeri 4,559 dan setelah diberikan kompres hangat rerata skala nyeri menjadi 2,618, rerata skala penurunan nyeri sebesar 1,941 .

Dari data tersebut dapat disimpulkan bahwa usia dan jenis kelamin mempengaruhi terjadinya gout arthritis. Gout arthritis lebih banyak ditemukan pada pria dibandingkan pada Wanita. Pada wanita menopause memiliki risiko tinggi terjadinya gout arthritis disebabkan karena penurunan hormon esterogen, Memberikan kompres hangat adalah tindakan nonfarmakologi yang sangat efektif mudah dilakukan semua orang karena untuk bahan dan alatnya yang sangat mudah didapatkan, kompres hangat ini dapat membantu menurunkan nyeri pada penderita gout arthritis, selain menurunkan nyeri kompres hangat juga memberikan rasa nyaman dan hangat serta memperlancar sirkulasi darah serta mengurangi atau mencegah terjadinya spasme otot.

\section{KESIMPULAN}

Gout arthritis menyerang pada pria dewasa diatas 30 tahun dan pada Wanita meningkat setelah menopause. Meni,bulkan nyeri hebat, kulit bewarna merah, terasa panas dan bengkak. Kompres hangat mampu melancarkan sirkulasi darah dan meningkatkan relaksasi otot pada area inflamasi.

Lima jurnal yang direview membuktikan kompres hangat dapat secara signifikan menurunkan skala nyeri pada pasien dengan gout arthritis. Kompres hangat dapat direkomendasikan sebagai terapi non farmakologis untuk menurunkan nyeri pada gaout arthritis.

\section{DAFTAR PUSTAKA}

Agarwal, Akhsata. (2014). Ketahui Tentang Artritis Gout, Penyebabnya, Dan Pengobatan Rumahan. Diakses pada 20 
Aldhila Putri Widyastuti : Pengaruh Kompres Hangat Terhadap Penurunan Nyeri Pada Pasien Gout Arthritis

Januari $2021 \quad$ di

https://www.infehealthcare.com/2014/03/

29/suffering-gouty-arthritis/

Amilia,Rezky.(2013). Pengaruh Kompres Hangat Terhadap Nyeri Artritis Gout Pada Lanjut Usia Di Kampung Tegalgendu Kecamatan Kotagede Yogyakarta. Yogyakarta : Sekolah Tinggi Ilmu Kesehatan 'Aisyiyah, diakses pada 22 Juni 2021 di http://digilib.unisayogya.ac.id/641/1/NAS KAH\%20PUBLIKASI.pdf

Angriani, Eni, dkk. (2018). Faktor-Faktor Yang Berhubungan Dengan Kejadia Gout Arthritis Masyarakat Melayu. Riau : Fakultas Keperawatan Universitas Riau, diakses pada Sabtu 16 Januari 2021 di https://digilib.unri.ac.id/index.php/index. php? $\mathrm{p}=$ show detail\&id=74698\&keyword $\underline{\mathrm{s}=}$

Ardani, Intan Octa. (2019). Pengaruh Kompres Air Hangat Terhadap Penurunan Skala Nyeri Pada Penderita Gout Arthritis Di Puskesmas Dagangan Kecamatan Dagangan Kabupaten Madiun. Stikes Bhakti Husada Mulia, diakses pada Selasa 15 Desember 2020 di http://repository.stikesbhm.ac.id/677/1/1.pdf

Ardhiatama, Firman, dkk.(2017). Hubungan Antara Pengetahuan Tentang Gout Arthritis Terhadap Perilaku Pencegahan Gout Arthritis Pada Lansia. Stikes Buana Husada Ponorgo, diakses pada sabtu 16 Januari $2021 \quad$ di http://jurnal.csdforum.com/index.php/GH S/article/view/79

Ariana,Sofi.(2016). Stop Gagal Ginjal.Istana Media, diakses pada Selasa 22 Juni 2021 di

https://www.google.co.id/books/edition/S top_gagal_ginjal/mFBDAQAACAAJ?hl $=\mathrm{id}$

Bawiling,Nancy S,dkk.(2017). Hubungan Konsumsi Alkohol Dengan Kejadian Gouty Artritis Pada Pria Di Puskesmas Motoling Kecamatan Motoling. Universitas Negri Manado, diakses pada $\begin{array}{llll}\text { Selasa } & 22 & \text { Juni } & 2021\end{array}$ https://ejournal.unsrat.ac.id/index.php/kes mas/article/view/22980

Dianati, Nur Amalina. (2015). Gout And Hyperuricemia. Lampung : Universitas Lampung, diakses pada Jumat 27 November $2020 \quad$ di http://juke.kedokteran.unila.ac.id/index.p $\mathrm{hp} / \mathrm{majority} /$ article/view/555

Fajriyah, Nuniek Nizmah, dkk. (2013). Efektifitas Kompres Hangat Terhadap Skala Nyeri Pada Pasien Gout. Stikes Muhammadiyah Pekajangan, diakses pada Sabtu 24 Oktober 2020 di https://www.neliti.com/publications/9665 8/efektifitas-kompres-hangat-terhadapskala-nyeri-pada-pasien-gout

Feron, Meilania.(2019). BAB II Tinjauan Pustaka. Poltekkes Tanjungkarang, diakses pada Sabtu 17 Januri 2021 di http://repository.poltekkestkj.ac.id/289/3BAB\%2520II.pdf

Hermayudi, dkk. (2017). Penyakit Rematik (Rhemuatologi). Yogyakarta : Nuha Medika

Hikmatyar,Gulbuddin, dkk. (2017). Penatalaksanaan Komprehensif Artritis Gout dan Oesteoarthritis pada Buruh Usia Lanjut. Lampung : Fakultas Kedokteran Universitas Lampung, diakses pada Sabtu 28 November 2020 di http://repository.lppm.unila.ac.id/5166//

Hoesny, Rezkiyah, dkk.(2018). Pengaruh Kompres Hangat Terhadap Skala Nyeri Pada Pasien Gout Arthritis Di Wilayah Kerja Puskesmas Wara Kota Palopo Tahun 2017. Stikes Kurnia Persada Palopo, diakses pada Sabtu 24 Oktober 2020 di https://stikeskjp-palopo.ejournal.id/JFK/article/view/18

Kalim,Handono,dkk. (2019). Reumatologi Klinik. Malang : UB Press

Kurnia, Hezy. (2019). Sistem Pakar Diagnosa Penyakit Gouty Arthritis Dengan Menggunakan Metode Foward Chaining. Padang : Universitas Putra Indonesia "YPTK" Padang, diakses pada Jumat 27 November $2020 \quad$ di http://lppm.upiyptk.ac.id/ojsupi/index.ph p/KOMTEKINFO/article/view/175 
Journal of Nursing and Health (JNH)

Volume 6 Nomor 2 Tahun 2021 Halaman : 84 - 94

Manampiring, Aaltje E,dkk.(2011). Prevalensi Hiperurisemia Pada Remaja Obese Di Kota Tomohon. Manado : Universitas Sam Ratulangi Manado, diakses pada selasa 22 Juni 2021 di http://repo.unsrat.ac.id/251/1/Prevalensi Hiperurisemia_pada_Remaja_Obese_Di_ Kota_Tomohon.pdf

Noviyanti. (2015). Hidup Sehat Tanpa Asam Urat. Yogyakarta : Notebook

Pamungkas, Tsalia Indah (2019). Perbedaan Penilaian Skala Nyeri Antara Menggunakan Numeric Rating Scale Dan Wong-Baker Faces Pain Rating Scale Terhadap Manifestasi Perilaku Nyeri Pada Pasien Bedah Anak Di RSUD Dr.H.Abdul Moeloek Lampung 2019. Poltekkes Tanjungkarang, diakses pada Sabtu 16 Januari 2021 di http://repository.poltekkestjk.ac.id/479/3/2.pdf

Perhimpunan Reumatologi Indonesia. (2014). Penggunaan Obat Anti Inflamasi Non Steroid. Diakses pada 26 Januari 2021 di https://reumatologi.or.id/wpcontent/uploads/2020/10/Rekomendasi_O AINS_2014.pdf

Perhimpunan Rheumatologi Indonesia.(2018). Pedoman Diagnosis dan Pengelolaan Gout, di akses pada senin 28 Desember 2020

https://reumatologi.or.id/download/pedo man-diagnosis-dan-pengelolaan-gout/

R, Zahara. (2013). Artritis Gout Metakarpal Dengan Perilaku Makan Tinggi Purin Diperberat Oleh Aktifitas Mekanik Pada Kepala Keluarga Dengan Posisi Mengenggam Statis. Lampung : Fakultas Kedokteran Universitas Lampung, diakses pada Minggu 22 November 2020 di

http://juke.kedpkteran.unila.ac.id/index.p hp/medula/article/download/115/113

Radharani, Radhika. (2020). Kompres Jahe Hangat dapat Menurunkan Intensitas Nyeri pada Pasien Gout Artritis. Lampung : Fakultas Kedokteran Universitas Lampung, diakses pada Sabtu 24 Oktober 2020 di https://akper- sandikarsa.e-

journal.id/JIKSH/article/view/349

Risal, Muhammad. (2019). Efektifitas Kompres Hangat Terhadap Penurunan Skala Nyeri Pada Pasien Gout Arthritis Di Wilayah Kerja Puskesmas Tomoni Luwu Timur. Luwu Timur : STIKES Batara Guru Soroaka, diakses pada Sabtu $24 \quad$ Oktober $2020 \quad$ di https://ojs.stikesgrahaedukasi.ac.id/index. php/JIKKHC/articleVIEW/157

Rosyid, Imron, dkk. (2019). Metodologi Penelitian. Yogyakarta : UMY, diakses pada senin 14 Desember 2020 di http://repository.umy.ac.id/bitstream/hand le/123456789/7.\%20BAB\%20III.pdf?seq uence $=5 \&$ is Allowed $=\mathrm{y}$

Sari, Deby Puspita. (2016). Pengaruh Kompres Hangat Dengan Penurunan Nyeri Sendi Pada Pasien Gout Artritis Di Wilayah Kerja Puskesmas Pringsewu Kabupaten Pringsewu Lampung Tahun 2016. Lampung : Stikes Muhammadiyah Pringsewu Lampung, di akses pada selasa 15 Desember 2020 di https://stikesmuhpringsewu.ac.id/perpustakaan/index.php? $\mathrm{p}=$ fstream-pdf \&fid $=491 \& \mathrm{bid}=2524$

Sembiring, Samuel Pola Karta. (2018). Diagnosa Diferensial Nyeri Lutut. SamuelKarta, diakses pada Rabu 25 November $\quad 2020 \quad$ di https://books.google.co.id

Sholihah, Fatwa Maratus. (2014). Diagnosa And Treatment Gout Arthritis. Lampung : Universitas Lampung, diakses pada Jumat 25 Desember 2020 di https://juke.kedokteran.unila.ac.id/index.p hp/majority/article/download/475/476

Siregar,Munawaroh,dkk.(2018). Efektifitas Kompres Hangat Terhadap Penurunan Nyeri Sendi Penderita Gout Arthritis. Riau : Fakultas Keperawatan Universitas Riau, diakses pada 22 Juni 2021 di https://jom.unri.ac.id/index.php/JOMPSI K/article/download/21029/20351

Sukarmin.(2015). Faktor-Faktor Yang Berhubungan Dengan Kadar Asam Urat Dalam Darah Pasien Gout Di Desa Kedungwinong Sukolilo Pati. Stikes Muhammadiyah Kudus, diakses pada 
Aldhila Putri Widyastuti : Pengaruh Kompres Hangat Terhadap Penurunan Nyeri Pada Pasien Gout Arthritis

jumat 25 Desember 2020 di

https://publikasiilmiah.ums.ac.id/xmlui/h andle/11617/6893

Widyanto, Fandi Wahyu. (2014). Artritis Gout Dan Perkembangannya. Blitar : Rumah Sakit Amanah, diakses pada senin 28 Desember $2020 \quad$ di http://ejournal.umm.ac.id/index.php/sain med/article/view/4182

Wurangin, Melyynda, dkk. (2014). Pengaruh Kompres Hangat Terhadap Penurunan Skala Nyeri Pada Penderita Gout Arthritis Di Wilayah Kerja Puskesmas Bahu Manado. Manado : Universitas Sam Ratulangi Manado, diakses pada Sabtu 24 Oktober 2020 di https://ejournal.unsart.ac.id/index.php/jkp /article/view/5264

Yuda, Hendri Tamara, dkk. (2017). Penerapan Terapi Kompres Hangat Untuk Menurunkan Demam Pada Klien Thypoid Di RSUD Dr.Soedirman Kebumen. Stikes Muhammadiyah Gombong, diakses pada Jumat 27 November $2020 \quad$ di http://elib.stikesmuhgombong.ac.id/973/1 /Penlit\%20Studi\%20Kasus\%kompres\%h angat.pdf

Yudiyanta,dkk.(2015). Assessment Nyeri. Yogyakarta : Departemen Neurologi, Fakultas Kedokteran Universitas Gadjah Mada, diakses pada Jumat 22 Januari 2021

http://www.academia.edu/download/5487 2538/19_226TeknikAssessment Nyeri.pdf

Zahroh, Chilyatiz, dkk. (2018). Pengaruh Kompres Hangat Terhadap Penurunan Nyeri Pada Penderita Penyakit Artritis Gout. Surabaya : Universitas Nahdlatul Ulama Surabaya, di akses pada 24 Oktober $2020 \quad$ di http://jnk.phb.ac.id/index.php/jnk/article/ view/328 